\section{Pre-school teacher candidates' attitudes towards children rights in term of some variables}

\section{Okul öncesi öğretmen adaylarının çocuk haklarına ilişkin tutumlarının çeşitli değişkenlere göre incelenmesi $^{1}$}

\author{
Yasin Doğan ${ }^{2}$ \\ Fatma Torun ${ }^{3}$ \\ İsmail Hakan Akgün ${ }^{4}$
}

\begin{abstract}
Today, the value given to children is increased and with the increased of this value, children's rights has started to appear among the issues that are often raised. In this respect, to teach rights effectively to children is very important from very young age. The aim of this study is to determined pre-school teachers' attitudes toward children's rights. Sample of the study consists of 382 teacher candidates who are training in Adıyaman, Kilis 7 Aralık, İnönü, Atatürk, Kafkas, and Muş Alparslan Universities Pre- school Education Programme. The study is realized descriptive research approaches, based on the model of survey. As a means of data collection is used "Children's Rights Attitude Scale" The data obtained were analysed by using SPSS program and suggestions were made in accordance with the results. There has been found no significant difference between the attitudes of pre-service teachers towards the child rights according to the variables of class level, educational level of parents, monthly income level of the family and taking the lesson
\end{abstract}

Özet

Günümüzde çocuğa verilen değer artmış ve çocuğa verilen değerin artmasıyla birlikte çocuk hakları da sik sik gündeme gelen konular arasında yer almaya başlamıștır. Bu açıdan çocuklara çok küçük yaşlardan itibaren haklarını etkili bir şekilde öğretmek oldukça önemlidir. Bu çalışma, okul öncesi öğretmen adaylarının çocuk haklarına ilişkin görüșlerini belirlemek amacıyla yapılmıștır. Çalışmanın evrenini okul öncesi öğretmenliği programlarında öğrenim gören öğretmen adayları; örneklemini ise Adıyaman, Kilis 7 Aralık, İnönü, Atatürk, Kafkas ve Alpaslan Üniversitelerinin okul öncesi öğretmenliği programında öğrenim gören toplam 382 öğretmen adayı oluşturmaktadır. Çalışma tarama modeline dayalı olarak gerçekleştirilmiştir. Veri toplama araci olarak "Çocuk Hakları Tutum Ölçeğì" (ÇHTÖ) kullanılmıștır. Elde edilen veriler SPSS 15.00 analiz programı kullanılarak analiz edilmiş ve sonuçlar doğrultusunda önerilerde bulunulmuştur. Okul öncesi öğretmen adaylarının çocuk haklarına ilişkin tutumları

\footnotetext{
1 Bu çalışma, Marmara Üniversitesinde düzenlenen I. Uluslararası Sosyal Bilgiler Öğretimi Sempozyumuna sunulmuş bildirinin geliştirilmiş şeklidir.

2 Yrd. Doç. Dr., Adıyaman Üniversitesi, Eğitim Fakültesi İlköğretim Bölümü, ydogan@adivaman.edu.tr

3 Arş. Gör., Adıyaman Üniversitesi, Eğitim Fakültesi Ilköğretim Bölümü, ftorun@,adiyaman.edu.tr

${ }^{4}$ Yrd. Doç. Dr., Adıyaman Üniversitesi, Eğitim Fakültesi İlköğretim Bölümü, hakgun@adivaman.edu.tr
} 
Doğan, Y., Torun, F., \& Akgün, H. (2014). Okul öncesi öğretmen adaylarının çocuk haklarına ilișkin tutumlarının çeșitli değişkenlere göre incelenmesi. International Journal of Human Sciences, 11(2), 503-516. doi: $10.14687 /$ ijhs.v11i2.2998

concerning child rights however there has been noticed a significant difference according to the variables of number of siblings.

Keywords: Children Rights, Attitudes, PreSchool, Teacher Candidates,

(Extended English abstract is at the end of this document)

\section{Giriş}

Çocuk kavramı; Eğitim Terimleri Sözlüğünde "Bebeklik çağ1 ile erginlik çağ1 arasındaki gelişme döneminde bulunan insan” (BSTS / Ĕ̆itim Terimleri Sözlüğü, 1974) olarak tanımlanmıştır. Kişinin geçirmiş olduğu bu döneme de çocukluk denmektedir. Çocukluk insan hayatındaki en önemli dönemlerinden birisidir. Çünkü bu dönem, insanın yetişkinlik döneminin de şekillenmesini sağlayacak olan dönemdir. Akyüz, bu dönem için "Çocukluk, bebekliğin tersine doğal bir gerçeklik değil, sosyo-kültürel bir kavramdır. Bu nedenle de öteki toplumsal kavramlar gibi norm ve değerlere göre göreceli olarak belirlenir” ifadesini kullanmıştır (Akyüz, 2001: 1).

Çocuk Haklarına Dair Sözleşme’nin 1. maddesinde "Bu sözleşme uyarınca çocuğa uygulanabilecek olan kanuna göre erken yaşta reşit olmak durumu hariç, on sekiz yaşına kadar her insan çocuk sayılıı” denmektedir (Çocuk Haklarına Dair Sözleşme, 1989).

Çocukluk insan yaşamında bu kadar önemli olmasına rağmen uzun yıllar çocuklara ve çocukluk dönemine gereken önem verilmemiştir. Binlerce yıl tüm dünyada çocuk, "küçük insan" ya da "insan ufağı" olarak nitelendirilmiştir. Geçmiş dönemlerde yaşayan insanlara göre insan yaşamı, "bebeklik, yetişkinlik ve yaşlılık" olmak üzere üç dönemden oluşmaktaydı. İnsan yaşamında çocukluk diye bir dönem bulunmamaktaydı (Akyüz, 2010: 1).

Çocukluğun yetişkinlikten farklı bir dönem olduğu ve çocuğun minyatür yetişkin olmadığ1 görüşü batı dünyasında 17. yüzyılda ortaya çıkmıştır ( Elkind, 2001: 15). 20. yüzyıla gelindiğinde ise çocuğun insan ufağ1 olmadığ1, onun da kendine özgü duygu ve düşüncelerinin olduğu görüşü yaygınlık kazanmaya başlamıştır. Bu yüzyılda çocuk, toplumun geleceğini belirleyen en önemli insan kaynağı olarak değerlendirilmiştir. Bu yüzyıl aynı zamanda, filozofların, eğitimcilerin, psikologların ve hukukçuların çocukları incelemeleri, onların gelişimleri ve hakları konusunda fikirler ileri sürmeleri nedeniyle "çocuk yüzyılı" olarak da adlandırılmıştır (Akyüz, 2001: 11). 20. yüzyılın egemen çocuk paradigması, çocukluğun özel bir kategori olduğu temeline oturmaktadır. Özellikle çocukların sahip oldukları haklar 20. yüzyılın ikinci yarısında iyice şekillenmiş ve hukuki metinlerde yer almaya başlamıştır. Özel hukuk, sosyal hukuk, kamu hukuku ve uluslararası hukukta yer alan kuralların 
Doğan, Y., Torun, F., \& Akgün, H. (2014). Okul öncesi öğretmen adaylarının çocuk haklarına ilișkin tutumlarının çeșitli değişkenlere göre incelenmesi. International Journal of Human Sciences, 11(2), 503-516. doi: $10.14687 /$ ijhs.v11i2.2998

çocuklara tanıdığı yetkiler şekillenmiş ve “çocuk hakları" şeklinde düzenlenmiştir (İnan, 1968; Akt.: Karaman Kepenekçi ve Baydık, 2009: 330).

Günümüzde çocukların özel haklara sahip oldukları neredeyse tüm dünya tarafindan resmi şekilde kabul edilmesine rağmen hâlâ dünyada bu hakları kullanamayan binlerce belki de milyonlarca çocuk bulunmaktadır. Bunun en büyük nedeni ise çocukların sahip oldukları pek çok haktan habersiz olmalarıdır. Özellikle ülkemiz gibi oldukça fazla genç nüfusa sahip ülkelerde bu durum daha belirgin şekilde görülmektedir. Karaman Kepenekçi (2010) “Türkiye'de Çocuklar İçin Tavsiye Edilen Hikâyelerde Çocuk Hakları Üzerine Bir Analiz" adlı çalışmasında çocukların haklarını bilmelerinin en önemli hakları olduğunu ve bu sebepten çocuk hakları eğitimine daha fazla önem verilmesi gerektiğini belirtmektedir.

Kop ve Tuncer'in (2010) yaptıkları "Sosyal Bilgiler Öğretmenlerinin Çocuk Haklarını Algılamaları” başlıklı çalışmalarında öğretmenlerin, Türk toplumunda çocuk gerçeğinin Çocuk Hakları Sözleşmesi ile öngörülen bazı hedeflerin gerisinde olduğunu ifade ettiklerini belirtmişlerdir.

Çocukların, haklarını en iyi şekilde kullanabilmeleri için öncelikle hangi haklara sahip olduklarını öğrenmeleri gerekmektedir. Çocuklar sahip oldukları hakların bir kısmını yaşadıkları doğal çevrede gizil öğrenme yoluyla öğrenirken, bir kısmını da eğitim kurumlarında kasıtlı olarak öğrenmektedirler. Ülkemizde bu hakların öğretimi ile ilgili konular okul öncesi dönemden başlamak üzere her kademenin öğretim programında bulunmaktadır.

Bu programların amacına kavuşmasını ve haklarını bilen bireylerin yetişmelerini sağlayacak olan kişiler ise hiç şüphesiz programın uygulayıcıları olan öğretmenlerdir. Öğretmenlerin programı etkili şekilde yürütüp kazanımların amacına kavuşmasını sağlamak için öğretilecek konulara ilişkin olumlu tutum içinde olmaları ise diğer bir önemli konudur.

Okulöncesi dönemde de eğitim gören çocuklar haklarının bir kısmını ailesinden ve çevresinden öğrenirken bir kısmını da okulda formal bir bir şekilde öğrenmektedirler. Bu hakların öğretilmesinden sorumlu olan okul öncesi öğretmen adaylarının çocuk haklarına ilişkin tutumları da önemlidir.Özellikle ülkemizde 2000 li ylllardan sonra Avrupa Birliği sürecinde birçok çalışma yapılmış (Karaman Kepenekçi 2006; Aktürk 2006; Fazlıoğlu 2007; Neslitürk ve Ersoy 2007; Tunç 2008; Ay Zöğ 2008; Karaman Kepenekçi 2010; Merey ve Parpucu, 2012; Merey, 2012) ve bu çalışmar genelde Türkiye'de çocuk haklarının güvenliği, öğrenci, öğretmen, öğretmen adayı ve yöneticilerin çocuk haklarına ilişkin görüşleri, ders kitapları ve özellikle öğrenciler için hazırlanmış olan çocuk edebiyatı ürünlerinde çocuk haklarının ele alınışı ve çocuk haklarının uygulama sürecine ilişkin konular ele alınmıştır. Ancak son yıllarda özellikle çocukluğun ilk yılları olarak kabul edilen okul öncesi dönemin önemli bilgi kaynağı olan okul öncesi öğretmenleri ve öğretmen adaylarıyla 
Doğan, Y., Torun, F., \& Akgün, H. (2014). Okul öncesi öğretmen adaylarının çocuk haklarına ilișkin tutumlarının çeșitli değişkenlere göre incelenmesi. International Journal of Human Sciences, 11(2), 503-516. doi: 10.14687/ijhs.v11i2.2998

ilgili fazla çalışma yapılmamıştır. Ayrıca okul öncesinde okullaşma oranının en düşük olduğu Doğu ve Güneydoğu Anadolu bölgesi açısından da yukarıda belirtilen örneklem grubu ile ilgili çalışmaya rastlanmamıştır. Bu çalışma, okulöncesi öğretmen adayları ile ve onların çocuk haklarına ilişkin görüşlerini ortaya koymak ve çeşitli değişklerle durumlarını ortaya koymak amacıyla yapılmıştır. $\mathrm{Bu}$ amacı gerçekleştirmek için aşağıdaki sorulara cevap aranmıştır:

1. Okul öncesi öğretmen adaylarının çocuk haklarına ilişkin tutumları düzeyleri;

a) Sınıf seviyelerinegore anlamlı bir farkl111k göstermekte midir?

b) Anne eğitim düzeyine gore anlamlı bir farklılık göstermekte midir?

c) Baba eğitim düzeyine gore anlamlı bir farklılık göstermekte midir?

d) Ailenin aylık gelir düzeyine gore anlamlı bir farklılık göstermekte midir?

e) Kardeş sayısına gore anlamlı bir farklılık göstermekte midir?

f) Çocuk haklarına ilişkin ders alma durumlarına gore anlamlı bir farklılık göstermekte midir?

\section{Yöntem}

Araştırma nicel araştırma yöntemi kullanılarak yapılımışır. Bu bölümde araştırmanın modeli, evren ve örneklemi, veri toplama aracı ve verilen çözümlenmesi yer almaktadır.

\subsection{Araştırmanın Modeli}

Bu çalışmada tarama modeli kullanılmıştır. Tarama modeli olarak betimsel tarama modeli tercih edilmiştir. Tarama modelleri geçmişte var olmuş veya halen var olan mevcut durumu tespit etmek amacıyla yürütülen araştırma yaklaşımıdır (Çepni, 2009: 62). Bu araştırma modelinde araştırlan olaya, nesneye veya bireye herhangi bir müdahalede bulunulmaz. Sadece mevcut problem tespit edilmeye çalışılır (Karasar, 2007: 77).

\subsection{Evren ve Örneklem}

Araştırmanın evrenini Doğu ve Güneydoğu Anadolu Bölgeleri’nde bulunan üniversitelerin Okul Öncesi Öğretmenliği Lisans Programında öğrenimlerine devam etmekte olan 1. ve 4. sınıf öğretmen adayları oluşturmaktadır. Özellikle üniversite eğitimine başlangıcın ve olgunlaşmanın göstergesi olarak 1. Sınıf ve son sınıf öğrencilerinin eğitim süreci önemli bir değişken olarak değerlendirilmiştir.

Araştırmanın örneklemini ise Adıyaman, İnönü, Kilis 7 Aralık, Atatürk, Kafkas ve Muş Alparslan Üniversiteleri'nin Okul Öncesi Öğretmenliği Lisans Programı’nın 1. ve 4. sinıflarında öğrenimlerine devam etmekte olan toplam 382 öğretmen adayı oluşturmaktadır. 2011-2012 bahar döneminde okul öncesi öğretmenliği programına devam eden öğrencilerin ilgili sınıflarının büyük bır kısmına ulaşılmışır. Bu açıdan amaçlı ve kapsamlı örneklem seçilmiştir. 
Doğan, Y., Torun, F., \& Akgün, H. (2014). Okul öncesi öğretmen adaylarının çocuk haklarına ilișkin tutumlarının çeșitli değişkenlere göre incelenmesi. International Journal of Human Sciences, 11(2), 503-516. doi: $10.14687 /$ ijhs.v11i2.2998

\subsection{Veri Toplama Arac1}

Okul öncesi öğretmen adaylarının çocuk haklarına ilişkin tutumlarını belirlemek amacıyla daha önce Kepenekçi (2006) tarafından geliştirilen "Çocuk Haklarına İlişkin Tutum Ölçeği”" (ÇHTÖ) kullanılmıştır. Ölçek 5’li likert formunda hazırlanmış olup, “Tamamen Katıllyorum”, "Kat1liyorum", “Kararsızım", "Katılmıyorum” ve "Tamamen Katılmıyorum” seçenekleri bulunmaktadir.

Ölçekte çocukların dört farklı alandaki (yaşamsal, gelişimsel, korunma ve katılım) haklarına ilişkin 22 madde bulunmaktadır. Ölçekteki ifadelerin 19'u olumlu, 3’ü olumsuzdur. Olumsuz ifadelere (2., 14. ve 15. maddeler) verilen tepkiler ters puanlanmaktadır. Ölçekten alınacak en düşük puan 22 ve en yüksek puan ise 110 'dur.

Karaman Kepenekci (2006) ölçeğin geçerliğine ve güvenirliğine ilişkin yaptığ1 çalışma sonucunda, ölçeğin tek faktörlü olduğunu, ölçekteki maddelerin madde toplam korelasyon katsayılarının. 32 ile. 61 arasında değiştiğini, Cronbach Alpha iç tutarlılık katsayısının. 85, yarı test güvenirlik katsayısının ise. 77 olarak belirlendiğini ifade etmiştir. Bu araştırma için tutum ölçeğinin Cronbach Alpha iç tutarllık katsayısı. 74 olarak tespit edilmiştir. Bu çalışma için ölçeğin güvenilir olduğunu göstermektedir.

\subsection{Verilerin Çözümlenmesi}

Araştırmada elde edilen verilerin istatistiksel analizi için SPSS 15.00 programı kullanılmıştır.

Öğretmen adaylarının çocuk haklarına ilişkin tutumları arasındaki farkların değişkenlere göre anlamlı farkllılı gösterip göstermediğini belirlemek amacıyla normal dağılım gösterdiğinden bağımsız gruplar t-testi ve tek yönlü ANOVA testi kullanılmışıı.

\section{Bulgular}

Bu bölümde araştırmanın problem durumunu çözümlemek için oluşturulan alt problemlerin sonuçları açıklanmaktadır.

Tablo 1. Okul öncesi öğretmen adaylarının sınıf düzeylerine göre çocuk haklarına ilişkin tutum puanlarının farklılığına ilişkin t-testi sonuçları

\begin{tabular}{lllllll}
\hline Gruplar & $\mathbf{N}$ & $\mathbf{X}$ & Ss & Sd & t & p \\
\cline { 1 - 3 } 1.Sinıf & 217 & 4,56 &, 34 & 380 & $-1,850$ & 0,065 \\
\cline { 1 - 4 } 4.Sınıf & 165 & 4,63 &, 37 & & & \\
\hline
\end{tabular}


Doğan, Y., Torun, F., \& Akgün, H. (2014). Okul öncesi öğretmen adaylarının çocuk haklarına ilișkin tutumlarının çeșitli değişkenlere göre incelenmesi. International Journal of Human Sciences, 11(2), 503-516. doi: $10.14687 /$ ijhs.v11i2.2998

Tablo 1'e göre okul öncesi öğretmen adaylarının çocuk haklarına ilişkin tutum puanları arasında anlamlı bir farklılık bulunmamıstır $[\mathrm{t}(380)=-1,850 \mathrm{p}>0.05]$. Birinci sınıfta okumakta olan öğretmen adaylarının çocuk haklarına ilişkin tutum puan ortalaması $\bar{X}=4,56$, dördüncü sınıf öğretmen adaylarının çocuk haklarına ilişkin tutum puan ortalaması ise 4,63 olarak bulunmuştur. Bu sonuca göre dördüncü sınıf öğretmen adaylarının, birinci sınıf öğretmen adaylarına göre çocuk haklarına yönelik tutumlarının daha yüksek olduğu görülmektedir.

Okul öncesi öğretmen adaylarının anne eğitim düzeylerine göre çocuk haklarına ilişkin tutum puan ortalamaları ve ANOVA sonuçları Tablo 2 ve 3’te gösterilmiştir.

Tablo 2. Okul öncesi öğretmen adaylarının anne eğitim düzeyi değişkenine göre çocuk haklarına ilişkin tutum puanlarının betimsel analiz sonuçları

\begin{tabular}{llcc}
\hline Anne eğitim düzeyi & $\mathbf{N}$ & $\overline{\boldsymbol{X}}$ & Ss \\
\hline Okuma yazma bilmiyor & 89 & 4,57 &, 31 \\
\hline İlkokul & 191 & 4,62 &, 37 \\
\hline Ortaokul & 40 & 4,53 &, 38 \\
\hline Lise & 45 & 4,53 &, 33 \\
\hline Lisans & 17 & 4,70 &, 25 \\
\hline Toplam & 382 & 4,5961 &, 35 \\
\hline
\end{tabular}

Tablo 3. Okul öncesi öğretmen adaylarının anne eğitim düzeyi değişkenine göre çocuk haklarına ilişkin tutum puanlarının farklılı̆̆ına ilişkin ANOVA testi sonuçları

\begin{tabular}{|c|c|c|c|c|c|}
\hline Varyansın kaynağ1 & KT & sd & KO & $\mathbf{F}$ & $\mathrm{p}$ \\
\hline Gruplar aras1 & ,694 & 4 & 174 & 1,386 & 238 \\
\hline Gruplar içi & 47,208 & 377 &, 125 & & \\
\hline Toplam & 47,903 & 381 & & & \\
\hline
\end{tabular}

Tablo 3’teki analiz sonuçları, anne eğitim düzeyi ile öğretmen adaylarının çocuk haklarına ilişkin tutum puan ortalamaları arasında anlamlı bir farkın olmadığını göstermektedir (F (4-377) $1,386=\mathrm{p}<.05)$. Başka bir deyişle öğretmen adaylarının çocuk haklarına ilişkin tutum puan ortalamaları anne eğitim düzeyine göre anlamlı bir şekilde değişmemektedir. Tablo 2'deki anne eğitim düzeyi farklarını ayrıntılı olarak görmek için aritmetik ortalamalara bakılmıştır. Tablo 2'deki ortalamalara göre annesi lisans mezunu $(\bar{X}=4,70)$ ve ilkokul mezunu $(\bar{X}=4,62)$ olan öğretmen adaylarının çocuk haklarına ilişkin tutum puan ortalamaları, annesi okuma yazma bilmeyen 
Doğan, Y., Torun, F., \& Akgün, H. (2014). Okul öncesi öğretmen adaylarının çocuk haklarına ilişkin tutumlarının çeşitli değişkenlere göre incelenmesi. International Journal of Human Sciences, 11(2), 503-516. doi: $10.14687 /$ ijhs.v11i2.2998

$(\bar{X}=4,57)$, ortaokul ve lise mezunu $(\bar{X}=4,53)$ olan öğretmen adaylarına göre daha yüksek bulunmuştur.

Okul öncesi öğretmen adaylarının baba eğitim düzeylerine göre çocuk haklarına ilişkin tutum puan ortalamaları ve ANOVA sonuçları Tablo 4 ve 5’te gösterilmiştir.

Tablo 4. Okul öncesi öğretmen adaylarının baba eğitim düzeyi değişkenine göre çocuk haklarına ilişkin tutum puanlarının betimsel analiz sonuçları

\begin{tabular}{llll}
\hline Baba eğitim düzeyi & $\mathbf{N}$ & $\overline{\boldsymbol{X}}$ & Ss \\
\hline Okuma yazma bilmiyor & 8 & 4,6932 &, 2486 \\
\hline İlkokul & 155 & 4,6111 &, 3239 \\
\hline Ortaokul & 67 & 4,5780 &, 3710 \\
\hline Lise & 79 & 4,5478 &, 4528 \\
\hline Lisans ve Üstü & 73 & 4,6275 &, 2888 \\
\hline Toplam & 382 & 4,5961 &, 3545 \\
\hline
\end{tabular}

Tablo 5. Okul öncesi öğretmen adaylarının baba eğitim düzeyi değişkenine göre çocuk haklarına ilişkin tutum puanlarının farklılı̆̆ına ilişkin ANOVA testi sonuçları

\begin{tabular}{|c|c|c|c|c|c|}
\hline Varyansın kaynağ1 & KT & Sd & KO & $\mathbf{F}$ & $\mathrm{p}$ \\
\hline Gruplararas1 & 371 & 5 & 074 & 586 & ,710 \\
\hline Gruplar içi & 47,532 & 376 & ,126 & & \\
\hline Toplam & 47,903 & 381 & & & \\
\hline
\end{tabular}

Tablo 5’in sonuçları, baba eğitim düzeyi ile öğretmen adaylarının çocuk haklarına ilişkin tutum puan ortalamaları arasında anlamlı bir farkın olmadığını göstermektedir (F (5-376), 586 = $\mathrm{p}<.05)$. Başka bir deyişle öğretmen adaylarının çocuk haklarına ilişkin tutum puan ortalamaları baba eğitim düzeyine göre anlamlı bir şekilde değişmemektedir. Tablo 4’teki baba eğitim düzeyi farklarını ayrıntılı olarak görmek için aritmetik ortalamalara bakılmıştır. Tablo 4’teki ortalamalara göre babası okuma yazma bilmeyen $(\bar{X}=4,69)$, lisans ve lisansüstü mezunu $(\bar{X}=4,62)$ olan öğretmen adaylarının çocuk haklarına ilişkin tutum puan ortalamaları, babası ilkokul mezunu $(\bar{X}=4,61)$, ortaokul mezunu $(\bar{X}=4,57)$ ve lise mezunu $(\bar{X}=4,54)$ olan öğretmen adaylarına göre daha yüksek bulunmuştur.

Okul öncesi öğretmen adaylarının aylık gelir düzeylerine göre çocuk haklarına ilişkin tutum puan ortalamaları ve ANOVA sonuçları Tablo 6 ve 7'de gösterilmiştir. 
Doğan, Y., Torun, F., \& Akgün, H. (2014). Okul öncesi öğretmen adaylarının çocuk haklarına ilişkin tutumlarının çeşitli değişkenlere göre incelenmesi. International Journal of Human Sciences, 11(2), 503-516. doi: $10.14687 /$ ijhs.v11i2.2998

Tablo 6. Okul öncesi öğretmen adaylarının aylık gelir düzeyi değişkenine göre çocuk haklarına ilişkin tutum puanlarının betimsel analiz sonuçları

\begin{tabular}{llll}
\hline Gelir düzeyi & $\mathbf{N}$ & $\overline{\boldsymbol{X}}$ & Ss \\
\hline $0-500 \mathrm{TL}$ & 49 & 4,5965 &, 27565 \\
\hline 501-1000TL & 99 & 4,5996 &, 31241 \\
\hline 1001-1500TL & 111 & 4,5616 &, 46141 \\
\hline 1501-2000TL & 59 & 4,6109 &, 26749 \\
\hline 2001 ve üzeri TL & 62 & 4,6422 &, 33305 \\
\hline Toplam & $\mathbf{3 7 9}$ & $\mathbf{4 , 4 5 4 5}$ & $\mathbf{1 9 2 8 5}$ \\
\hline
\end{tabular}

Tablo 7. Okul öncesi öğretmen adaylarının aylık gelir düzeyi değişkenine göre çocuk haklarına ilişkin tutum puanlarının farklılı̆̆ına ilişkin ANOVA testi sonuçları

\begin{tabular}{llllll}
\hline Varyansın kaynağı & KT & sd & KO & F & p \\
\cline { 1 - 4 } Gruplararası &, 318 & 5 &, 064 & \multirow{2}{*}{, 503} &, 774 \\
\cline { 1 - 4 } Gruplar içi & 47,584 & 376 &, 127 & & \\
\cline { 1 - 4 } Toplam & 47,903 & 381 & & & \\
\hline
\end{tabular}

Tablo 7'de aylık gelir düzeyi ile öğretmen adaylarının çocuk haklarına ilişkin tutum puan ortalamaları arasında anlamlı bir farkın olmadığı görülmektedir (F (5-376), 503 = p>.05). Başka bir deyişle öğretmen adaylarının çocuk haklarına ilişkin tutum puan ortalamaları aylık gelir düzeyine göre anlamlı bir şekilde değişmemektedir. Tablo 6'daki aylık gelir düzeyi farklarını ayrıntılı olarak görmek için aritmetik ortalamalara bakılmıştır. Tablo 6'daki ortalamalara göre aylık geliri 2000 ve üzeri TL $(\bar{X}=4,64)$ ve 1501-2000 TL $(\bar{X}=4,61)$ olan öğretmen adaylarının çocuk haklarına ilişkin tutum puan ortalamaları, aylık geliri 0-1500 TL ( $\overline{\boldsymbol{X}}=4,45)$ olan öğretmen adaylarına göre daha yüksek bulunmuştur.

Okul öncesi öğretmen adaylarının kardeş sayısına göre çocuk haklarına ilişkin tutum puan ortalamaları ve ANOVA sonuçları Tablo 8 ve 9'da gösterilmiştir. 
Doğan, Y., Torun, F., \& Akgün, H. (2014). Okul öncesi öğretmen adaylarının çocuk haklarına ilișkin tutumlarının çeșitli değişkenlere göre incelenmesi. International Journal of Human Sciences, 11(2), 503-516. doi: $10.14687 /$ ijhs.v11i2.2998

Tablo 8. Okul öncesi öğretmen adaylarının kardeş sayısı değişkenine göre çocuk haklarına ilişkin tutum puanlarının betimsel analiz sonuçları

\begin{tabular}{llll}
\hline Kardeş sayısı & $\mathbf{N}$ & $\overline{\boldsymbol{X}}$ & ss \\
\hline 1 & 6 & 4,1364 & 1,07103 \\
\hline 2 & 41 & 4,5876 &, 33269 \\
\hline 3 & 105 & 4,6521 &, 28391 \\
\hline 4 & 88 & 4,6188 &, 30778 \\
\hline 5 & 49 & 4,4944 &, 39207 \\
\hline 6 ve üzeri & 93 & 4,5982 &, 35484 \\
\hline Toplam & 382 & 4,5961 &, 35458 \\
\hline
\end{tabular}

Tablo 9. Okul öncesi öğretmen adaylarının kardeş sayısı değişkenine göre çocuk haklarına ilişkin tutum puanlarının farklılı̆̆ına ilişkin ANOVA testi sonuçları

\begin{tabular}{|c|c|c|c|c|c|c|}
\hline $\begin{array}{c}\text { Varyansın } \\
\text { kaynağ1 }\end{array}$ & $\mathrm{KT}$ & sd & $\mathrm{KO}$ & $\mathrm{F}$ & $\mathrm{p}$ & $\begin{array}{c}\text { Farkın } \\
\text { Kaynağ1 }\end{array}$ \\
\hline Gruplararas1 & 2,153 & 5 & ,431 & \multirow{3}{*}{3,539} & \multirow{3}{*}{,004* } & $3-2$ \\
\hline Gruplar içi & 45,749 & 376 & ,122 & & & $4-2$ \\
\hline Toplam & 47,903 & 381 & & & & $\begin{array}{l}6-2 \\
6-1\end{array}$ \\
\hline
\end{tabular}

Tablo 9'daki analiz sonuçları, kardeş sayısı ile öğretmen adaylarının çocuk haklarına ilişkin tutum puan ortalamaları arasında anlamlı bir farkın olduğunu göstermektedir (F (5-376), 3539 = $\mathrm{p}<.05)$. Başka bir deyişle öğretmen adaylarının çocuk haklarına ilişkin tutum puan ortalamaları kardeş sayısına göre anlamlı bir şekilde değişmektedir. Tablo 8'deki kardeş sayısı farklarını ayrıntılı olarak görmek için aritmetik ortalamalara bakılmıştır. Tablo 8'deki ortalamalara göre kardeş sayısı 3 $(\bar{X}=4,65), 4(\bar{X}=4,61)$ ve 6 ve üzeri $(\bar{X}=4,59)$ olan öğretmen adaylarının çocuk haklarına ilişkin tutum puan ortalamaları, kardeş sayısı $2(\bar{X}=4,58), \quad 5(\bar{X}=4,49)$ ve $1(\bar{X}=4,13)$ olan öğretmen adaylarına göre daha yüksek bulunmuştur. 
Doğan, Y., Torun, F., \& Akgün, H. (2014). Okul öncesi öğretmen adaylarının çocuk haklarına ilișkin tutumlarının çeșitli değişkenlere göre incelenmesi. International Journal of Human Sciences, 11(2), 503-516. doi: $10.14687 /$ ijhs.v11i2.2998

Tablo 10. Okul öncesi öğretmen adaylarının çocuk haklarına yönelik ders alma durumlarına göre çocuk haklarına ilişkin tutum puanlarının farklılı̆̆ına ilişkin t-testi sonuçları

\begin{tabular}{llcclll}
\hline Gruplar & $\mathbf{N}$ & $\overline{\boldsymbol{X}}$ & Ss & Sd & $\mathbf{t}$ & $\mathbf{p}$ \\
\cline { 1 - 5 } Ders Alanlar & 164 & 4,5618 &, 41376 & 380 & $\mathbf{- 1 , 6 4 2}$ & $\mathbf{1 0 1}$ \\
\cline { 1 - 5 } Ders & 218 & 4,6219 &, 30100 & & & \\
Almayanlar & & & & & & \\
\hline
\end{tabular}

Tablo 9’a göre okul öncesi öğretmen adaylarının çocuk haklarına yönelik ders alma durumlarına göre çocuk haklarına ilişkin tutum puanları arasında anlamlı bir farklılık bulunmamıştır $[t(380)=-1,642 \mathrm{p}>0.05]$. Çocuk haklarına yönelik ders alan öğretmen adaylarının çocuk haklarına ilişkin tutum puan ortalaması $\overline{\boldsymbol{X}}=4,56$, ders almayan öğretmen adaylarının çocuk haklarına ilişkin tutum puan ortalaması ise $\overline{\boldsymbol{X}}=4,62$ olarak bulunmuştur. Çocuk haklarına yönelik ders alan ve almayan öğretmen adaylarının tutum puan ortalamaları arasında bir fark bulunmaktadır ancak bu fark anlamlı düzeyde değildir. Bu sonuca göre çocuk haklarına yönelik ders almayan öğretmen adaylarının, dersi alan öğretmen adaylarına göre çocuk haklarına yönelik tutumlarının daha yüksek olduğu görülmektedir. Bunun nedeni olarak araştırmaya katılan öğretmen adayları arasında çocuk haklarına yönelik ders almayan öğretmen adayı sayısının daha fazla olması gösterilebilir.

\section{Sonuç ve Tartışma}

Birleşmiş Milletlerin Çocuk Haklarına Dair Sözleşmesi'nin 28. maddesi ile Taraf Devletlere, hiçbir ayrım gözetilmeksizin bütün çocukların eğitim hakkına sahip olduğu belirtilmektedir. 29. madde çocuk merkezli bir öğretme ve öğrenme modelini öngörerek; öğrencilerin eğitim sürecine aktif biçimde katılacakları, kendi başlarına sorunlarını çözebilecekleri, yaşam boyu öğrenerek doğru kararlar verebilecek özgüveni kazanacakları bir yapıyı gündeme getirmektedir. Yine sözleşmenin 42. Maddesi, tüm taraf devletlere "Sözleşme ilke ve hükümlerinin uygun ve etkili araçlarla yetişkinler kadar çocuklar tarafindan da yaygın biçimde öğrenilmesini sağlama" yükümlülüğünü getirmiştir (ÇHS, 1989,). Bu madde gereğince taraf devletler, çocukların sahip oldukları hakların öğretilmesine yönelik bir yükümlüğe sahiptir. Haklarını bilmeyen bir kişide hak bilincinin ve hakkını kullanma yetisinin oluşması beklenemez. Bilgili, sorumlu, haklarından yararlanma yeteneği gelişmiş çocukların topluma kazandırılabilmesi ancak iyi bir temel eğitim olanağının sağlanmasına bağlıdır (Karaman Kepenekçi, 2000).

Özellikle çocuk hakları sözleşmesinde yukarıda bahsedilen maddesi kapsmanında pekçok ilgili paydaş üzerinde araştırmalar gerçekleştirilmiş ve bu araştırmalarda Rogers ve Wrightsman 
Doğan, Y., Torun, F., \& Akgün, H. (2014). Okul öncesi öğretmen adaylarının çocuk haklarına ilișkin tutumlarının çeșitli değişkenlere göre incelenmesi. International Journal of Human Sciences, 11(2), 503-516. doi: $10.14687 /$ ijhs.v11i2.2998

(1978), Morton ve Dubanoski (1980), Melton (1980) ve Ruck (1994), Yursever Kilıçün, Oktay; ) geliştirdiği ölçeklerle ; çocukların haklarına yönelik tutumların alt boyutlarını ortaya koymuşlardır.

Bu hüküm uyarınca, çocukların ÇHS ile kendilerine tanınan tüm haklar konusunda bilgi sahibi olmaları önemli olduğu için çocukların sahip olduğu bu hakların öğretmen adayları tarafindan bilinmesi gerekmektedir.

Araştırmada genel olarak okul öncesi öğretmen adaylarının çocuk haklarına yönelik tutum puanlarının oldukça yüksek olduğu sonucuna ulaşılmışır. Öğretmen adaylarının çocuk haklarına ilişkin tutumları arasında sınıf düzeyi, anne ve baba eğitim düzeyi, ailenin aylık gelir düzeyi ve çocuk haklarına ilişkin ders alma durumlarına göre anlamlı bir fark bulunamazken kardeş sayısı değişkenine göre anlamlı fark bulunmuştur.

Karaman Kepenekçi (2006), üniversite öğrencilerinin çocuk haklarına ilişkin tutumlarını belirlemek amacıyla yaptığı çalısmada sınıf düzeyinin ve insan hakları ile ilgili ders alma durumları değişkenleri açısından anlamlı fark çıkmadığını belirtmiştir. Ayrıca Campbell ve Covvel'in çalışması $(2001 ; 129)$ Üniversite 3. ve 4. Sinıfta öğrenim gören siyaset bilimi ve psikoloji öğrencilerinin çocuk haklarına yönelik ders alma durumlarının tutumlarında etkisi olmadığı sonucunu ortaya koymuştur. ocuk haklarına ilişkin olumlu tutum taşıma ile bu alanda verilecek eğitime duyarll11k gösterme arasında doğru bir orantı olduğu söylenebilir. Ancak Değirmenci (2011)çeşitli branşlarda öğrenim gören öğretmen adaylarıyla yaptığı araştırmada cinsiyet ve sınıf düzeyine göre öğretmen adaylarının çocuk haklarına ilisskin tutumları incelendiğinde bayan öğretmen adaylarının erkek öğretmen adaylarına göre daha olumlu olduğunu ortaya koymuştur. Bunun nedeninin bayanların içgüdüsel olarak çocuklara karşı daha şevkatli olmalarından kaynaklanabileceği şekliyle açılklamıştır. Dördüncü sınıf öğretmen adaylarının tutumlarının birinci sınıf öğretmen adaylarından olumlu olduğu sonucuna ulaşan Değirmenci, öğretmen adaylarının aldıkları eğitimin olumlu yönde etki ettiğini belirtmiştir. Ayrıca öğretmen adaylarının alanlarına göre incelendiğinde ise en olumlu tutum Okul Öncesi Öğretmenliği bölümünde okuyanlarda görüldüğünü bunun sebebi ise okul öncesi öğretmen adaylarının diğer bölümlere göre çocuklarla daha çok iç içe olmaları ve çocuk haklarına ilişkin ders almalarından kaynaklandığı şeklinde açıklanmıştır.

Neslitürk ve Ersoy (2007) okul öncesi öğretmen adaylarının çocuk haklarına ilişkin olumlu tutum içerisinde olduklarını belirtmiştir. Ay Zöğ (2008) ise lise öğrencileri ile yaptı̆̆ çalışmada öğrencilerin çocuk haklarına ilişkin tutumları anne ve baba eğitim düzeylerine göre değiştiğini ifade etmiştir. Karaman Kepenekçi ve Baydık’n (2009) bir başka çalışmasında Zihin engelliler öğretmenliği programına kayıtlı öğrencilerin çocuk haklarına ilişkin tutumlarının okul öncesi öğretmeni ve bilgisayar ve öğretim teknolojileri öğretmeni adaylarının tutumlarından farklılaşmadığı, 
Doğan, Y., Torun, F., \& Akgün, H. (2014). Okul öncesi öğretmen adaylarının çocuk haklarına ilișkin tutumlarının çeșitli değişkenlere göre incelenmesi. International Journal of Human Sciences, 11(2), 503-516. doi: $10.14687 /$ ijhs.v11i2.2998

bununla birlikte bu grubun tutumlarının sınıf öğretmenliği programına kayıtlı öğrencilerin tutumlarından daha olumsuz olduğu sonucuna ulaşılmıştır.

Elde edilen bu sonuçlardan hareketle aşağıdaki önerilerde bulunulmuştur. Ailede çocuğun kendini daha fazla ifade etmesine izin verilebilir. Demokratik aile ortamının oluşturulmasına yönelik kurslar düzenlenebilir.Okul öncesi öğretmen adaylarının aldıkları çocuk hakları içerikli derslerin daha uygulamalı ve nitelikli olması önerilebilir. Özellikle kardeş sayısı fazla olan öğretmen adaylarının diğer öğretmen adaylarına göre çocuk haklarında daha olumlu tutuma sahip olması üzerine detaylı ve boylamsal çalışmalar yapılabilir.

\section{Kaynakça}

Aktürk, S. (2006). Avrupa birliği sürecinde Türkiye’de çocuk haklarn ve güvenliği. Yüksek lisans tezi, Mustafa Kemal Üniversitesi, Sosyal Bilimler Enstitüsü, Hatay.

Akyüz, E. (2000). Çocuğun Haklarmm Ve Güvenlĭginin Korunması: Ankara: Milli Eğitim Bakanlı̆̆1 Yayınları, Bilim ve Kültür Eserleri Dizisi

Akyüz, E. (2001). Çocuk hakları sözleşmesinin temel ilkeleri 1şığında çocuğun eğitim hakkı. Milli Eg̈itim Dergisi, (151), 1-26.

Akyüz, E. (2010). Cocuk Hukuku. Pegem Akademi Yayınları: Ankara.

Ay Zöğ, D. (2008). Öğrencilerin çocuk haklarm algzlama dürgyleri ile akademik başarlar arasindaki iliski (Istanbul ili Beyoğlu ilçesi örneğı). Yüksek lisans tezi, Beykent Üniversitesi, Sosyal Bilimler Enstitüsü, İstanbul.

BSTS / Eğitim Terimleri Sözlüğü. (1974). TDK Yayınları: Ankara.

Campbell M.K. and Covell (2001). Children's rights education at the university level: An effective means of promoting rights knowledge and rights-based attitudes, The International Journal of Children's Rights 9:123-135

Çepni, S. (2009). Araștırma ve Proje Calş̧malarna Giriş. (4. Baskı), Trabzon

Çocuk Haklarına Dair Sözleşme(1989).,

http://www.cocukhaklari.gov.tr/tr/content/show/25/birlesmis milletler cocuk haklari bildirisi.h tml (10 Mart 2012)

Değirmenci, T. (2011), Öğretmen Adaylarının Çocuk Haklarına Yönelik Tutumlarının İncelenmesi,20 Ulusal Eğitim Bilimleri Kurultayı Bildirileri, Mehmet Akif Ersoy Üniversitesi, 8-10 Eylül 2011: Burdur

https://www.pegem.net/Akademi/kongrebildiri detay.aspx?id=125279 (10 Nisan 2014 tarihinde erişilmiştir.)

Doğanay, A. (2004). Sosyal Bilgiler Öğretimi, (Ed.: Cemil ÖZTÜRK ve Dursun DİLEK), Hayat Bilgisi ve Sosyal Bilgiler Öğretimi, (4. Baskı), Ankara: Pegema Yayıncılık

Elkind, D. (2001). Değişen dünyada çocuk yetiştirme ve eğitim. Dünyada Ve Türkiye'de Değişen Çocukluk, (Çev.: Emine Gül Kapçı), Ankara:Ankara Üniversitesi Çocuk Kültürü Araştırma Ve Uygulama Merkezi Yayınları

Fazlığlu, Z. (2007). Çocuk Haklar Sözlesmesinde Yer Alan "Çocuk Haklarn” Konusunda Öğretmenlerin ve Yöneticilerin Bilinc Düzeyleri. Yüksek lisans tezi, Yeditepe Üniversitesi, Sosyal Bilimler Enstitüsü, İstanbul.

Karasar, N. (2007). Bilimsel Araștırma Yöntemi. (17. Baskı), Ankara: Nobel Yayıncllı

Karaman Kepenekçi, Y. (2006). A study of university students' attitudes towards children's rights in Turkey. The International Journal of Children's Rights, (14), 307-319. 
Doğan, Y., Torun, F., \& Akgün, H. (2014). Okul öncesi öğretmen adaylarının çocuk haklarına ilișkin tutumlarının çeșitli değişkenlere göre incelenmesi. International Journal of Human Sciences, 11(2), 503-516. doi: $10.14687 /$ ijhs.v11i2.2998

Karaman Kepenekçi, Y. (2010). An analysis on children's rights in stories recommended for children in Turkey. Journal of Peace Education, 7(1), 65-83.

Karaman Kepenekçi, Y., Baydık, B., (2009). Zihinsel engelliler öğretmen adaylarının çocuk haklarına ilişkin tutumları, Ankara Üniversitesi Eğitim Bilimleri Fakültesi Dergisi, 42: 1, ss.329-350

Kop, Y. ve Tuncel, G. (2010). Sosyal bilgiler öğretmenlerinin çocuk haklarını algılamaları. Eğitimde Kuram ve Uygulama Dergisi, 6(1), 106- 124.

Merey, Z.(2012). “Türkizye ve ABD'deki ilkögretim sosyal bilgiler ders kitaplarnda okullarnda çocuklarn katulım haklarma yer verilme düzeyinin karşılaștırlması. Doktora tezi, Gazi Üniversitesi, Eğitim Bilimleri Enstitüsü, Ankara

Merey, Z. ve Parpucu, H. (2012). Inclusion level of children rights 1ssues in social studies textbooks (case of Turkey and USA), International Joumal of Early Childhood Education Research, 1 (1)

Morton, T. L., \& Dubanoski, R. A. (1980). Children's rights: Attitudes and perceptions. Educational Researcher. 19, 24-27.

Neslitürk, S. ve Ersoy, A. F. (2007). Okul öncesi öğretmen adaylarının çocuk haklarının öğretimine ilişkin görüşleri. Eğitimde Kuram Ve Uygulama Dergisi, 3(2), 245-257.

Tunç, D. (2008). Çocuk haklar sözllesmesinin eğitim politikalarna yansimalar konusunda Milli Eğitim Bakanlĭg uə̣manlarmm görüsleri. Yüksek lisans tezi, Ankara Üniversitesi, Eğitim Bilimleri Enstitüsü, Ankara

Rogers, C.M., \& Wrightsman, L.S. (1978). Attitudes toward children's rights: Nurturance or self-determination?. Journal of Social Issues, 34 (2), 59-68.

Yurtseven Kllı̧gün, M., Oktay, A. (2011). Çocuk haklarına yönelik ebeveyn tutum ölçeği’nin geliştirilmesi ve standardizasyonu, Dokuz Eylül Üniversitesi Buca Eğitim Fakültesi Dergisi S:31. ss.1-22

\section{Extended English Abstract}

The value given over the children has recently increased and child rights have taken its place among the most frequent current issues together with this increase at given value to children. The children who are aware of their rights will play a big role in development of the society as conscious adults. In this respect, it has been really important to teach children their rights as starting from their childhood. In our country, if there has been taken into consideration that the youngest student group has studied in pre-school teaching, it is obvious that attitudes of pre-services teachers, who will carry on their duties in pre-school teaching, concerning child rights are really important. The attitude that teachers have towards the subjects they teach will also affect their teaching performances. In the present day when child rights has had become a prominent issue all around the world, attitudes of teacher towards this issue has become important, as well. The purpose of this study is trying to determine attitudes of pre-school teachers concerning child rights.

The research has been carried out using quantitative research model. In this study, scanning model has been used. Scanning models are the ones that have been carried out to determine the current situation that existed in the past and has still existed (Cepni, 2009: 62). In this research model, there has been given no attention upon the under-researched event, object or individual. Only current problem has been tried to be determined (Karasar, 2007: 77). The study population has included 1st and 4th grade pre-service classroom teachers studying at the department of preschool teaching of educational faculties of universities in Eastern and Southeastern Anatolian regions in Turkey. And the study sample has included totally 382 pre-service teachers studying at 1 st and 4th grades of pre-school teaching departments of educational faculties in Adiyaman, Inonu, 
Doğan, Y., Torun, F., \& Akgün, H. (2014). Okul öncesi öğretmen adaylarının çocuk haklanına ilişkin tutumlarının çeşitli değişkenlere göre incelenmesi. International Journal of Human Sciences, 11(2), 503-516. doi: 10.14687/ijhs.v11i2.2998

Kilis 7 Aralik, Ataturk, Kafkas and Alparslan universities. In order to determine attitudes of preservice pre-school teachers towards child rights, there has been used "Attitude Scale Concerning the Child Rights" (ASCCR) developed by Kepenekci (2006). The scale has been prepared in 5-point likert form and it has included the choices of "I strongly agree", "I agree", "Neither agree nor disagree", "I disagree" and "I strongly disagree". The scale has included 22 items related to rights of children on four different fields (vital, developmental, protection and participation). Nineteen of the expressions in the scale were positive and 3 were negative. Reactions given to negative expressions (2nd, 14th and 15th) were graded inversely. The lowest grade that can be obtained from the scale was 22 and the highest was 110 . As result of the study concerning the validity and reliability of the scale Kepenekci (2006) has mentioned that the scale was single-factoral, total correlation coefficient of the items in the scale has ranged from 32 to 61, Cronbach alpha coefficient of internal consistency was .85 and test reliability coefficient was .77. The proper statistical program has been used for the analysis of the data obtained in the research. In order to determine whether the differences between attitudes of pre-service teachers towards child rights have displayed difference according to the variables, independent group t-test and ANOVA test have been performed.

\section{Results}

Analysis results of the obtained findings; there has been no difference between the attitude point averages of first and fourth grade pre-service teachers; however, this difference has been not at a significant level. According to this result, fourth grade pre-service teachers have been noticed to have higher attitudes towards child rights that the first grade pre-service teachers. Attitude point averages of pre-service teachers who have mothers with bachelor's degree and primary school graduate degree have had higher attitude point averages than the pre-service teachers who have illiterate or secondary education graduate degree mothers towards child rights. Attitude point averages of the pre-service teachers who have fathers with bachelor's degree and postgraduate degree have had higher attitude point averages than the pre-service teachers who have primary school graduate, secondary school graduate and high school graduate degrees. Attitude point averages of the pre-service teachers who have $2000 \mathrm{TL}$ and over and 1501-2000 TL monthly income towards child rights has been found as higher than the attitude point averages of the preservice teachers who have 0-1500 TL monthly income. Attitude point averages of the pre-service teacher who have 3, 4, 6 and over number of siblings towards child rights has been found as higher than the attitude point averages of pre-service teachers who have 2, 5 and 1 number of siblings. There has also been noticed that attitudes of pre-service teachers who have taken lesson concerning the child rights have had higher attitude point averages than the pre-service teachers who have not taken this course on child rights issue. The reason for this can be the higher number of pre-service teachers who have not taken this course among the ones who participated in this research.

\section{Discussion and Conclusion}

Whereas there has been found no significant difference between the attitudes of pre-service teachers towards the child rights according to the variables of class level, educational level of parents, monthly income level of the family and taking the lesson concerning child rights, there has been noticed a significant difference according to the variables of number of siblings. Kepenekçi (2006) has mentioned in his study which he carried out to determine attitudes of university students towards child rights that there has been no significant difference in terms of class level and taking course on human rights variables. Nesliturk and Ersoy (2007) have stated that pre-service preschool teachers have been in a positive attitude towards child rights. Zog (2008) have also mentioned in his study that was carried out with high school children that attitudes of students towards child rights have changed according to the educational levels of parents. 